\title{
Short-term efficacy of mandibular advancement splint in treatment of obstructive sleep apnea-hypopnea syndrome
}

\author{
Calliandra Moura Pereira de Lima1 ${ }^{1}$ Laurindo Zanco Furquim², Adilson Luiz Ramos ${ }^{3}$
}

Objective: The aim of the present study was to determine the short-term efficacy of treatment for snoring and obstructive sleep apnea-hypopnea syndrome (OSAHS) using a mandibular advancement splint. Methods: The sample comprised 20 patients ( 13 men and 7 women; mean age $=48$ years; mean body mass index $=27.07$ ) with OSAHS. Polysomnograms were performed before and 60 days after mandibular advancement splint therapy. Results: There was a significant reduction in the apnea-hypopnea index (AHI) following treatment (mean pretreatment AHI $=20.89$ \pm 17.9 versus mean posttreatment AHI $=4.43 \pm 3.09)(\mathrm{p}<0.05)$. The snoring reduced and the sleep efficiency improved, as registered by polysomnograms $(\mathrm{p}<0.05)$. Conclusions: The sleep quality improved in patients using mandibular advancement splint. Further studies evaluating long-term effects are needed.

Keywords: Sleep apnea syndrome. Snoring. Polysomnography.

Objetivo: verificar a eficácia e aceitação do tratamento de ronco e da SAHOS por meio de aparelho intrabucal. Métodos: a amostra foi composta de 20 pacientes de ambos os sexos (13 homens e 7 mulheres) que apresentavam SAHOS, com média de idade de 48 anos, e índice de massa corporal (IMC) médio de 27,07. Foram realizadas polissonografias pré- e pós-tratamento (60 dias) em todos os pacientes, e os sinais e sintomas foram analisados por meio de exame clínico após o uso de splint. Resultados: houve uma redução significativa do índice de apneia e hipopneia (IAH $=20,89 \pm 17,9 /$ hora) registrado no pré-tratamento, em comparação ao registrado durante o uso do aparelho intrabucal (IAH = 4,43 $\pm 3,09 /$ hora). A roncopatia, a eficiência do sono e o índice de saturação de oxigênio também mostraram melhoras e, consequentemente, a sonolência diurna, o cansaço e a irritabilidade diminuíram. Conclusões: apesar de algum desconforto relatado, houve boa aceitabilidade do aparelho por $60 \%$ dos pacientes, havendo melhora na qualidade do sono. Torna-se necessário um acompanhamento em médio e em longo prazo desses pacientes, com vistas ao ronco, à apneia do sono e aos efeitos colaterais decorrentes dessa modalidade de tratamento.

Palavras-chave: Síndromes da apneia do sono. Ronco. Polissonografia.

How to cite this article: Lima CMP, Furquim LZ, Ramos AL. Short-term efficacy of mandibular advancement splint in treatment of obstructive sleep apneahypopnea syndrome. Dental Press J Orthod. 2013 May-June;18(3):118-23.

${ }^{1}$ Specialist in Orthodontics, State University of Maringá (UEM/Brazil). MSc student in Health, Federal University of Santa Maria (UFSM/Brazil). ${ }^{2} \mathrm{PhD}$ in Oral Patology, Bauru Dental School. Head Professor of Orthodontics, UEM/Brazil.

${ }^{3} \mathrm{PhD}$ in Orthodontics, São Paulo State University (UNESP/Brazil).

Head Professor of Orthodontics, UEM/Brazil.
Submitted: March 25, 2011 - Revised and accepted: July 28, 2012

» The authors report no commercial, proprietary or financial interest in the products or companies described in this article.

» The patients displayed in this article previously approved the use of their facial and intraoral photographs.

Contact address: Calliandra Moura Pereira de Lima

Rua 7 de Setembro, 2500 - Centro - Campo Grande/MS - Brazil

CEP: 79.020-310 - E-mail: calli.pereira@bol.com.br 


\section{INTRODUCTION}

Snoring and sleep apnea stand out among the 84-catalogued diseases related to sleep disorders, affecting $10 \%$ of the population worldwide. More than 15 million Brazilians snore. With regard to sex, the proportion of men to women is 10:1, as men are more prone to the buildup of fat in neck and abdominal region ${ }^{16}$.

Sleep is essential to the homeostasis and restoration of the organism, including the central nervous system. Sleep is a dynamic physiological process involving the loss of consciousness and inactivation of the voluntary musculature, and is reversible through the effect of stimuli (tactile, auditory, somatosensory). ${ }^{9}$

Obstructive sleep apnea is a chronic, progressive respiration disorder involving the periodic interruption of breathing during sleep. ${ }^{28}$ This condition is characterized by the apposition of the tongue and soft palate on the lateral and posterior walls of the oropharynx, causing the collapse of these structures. The reduction in or complete absence of airflow varies with the severity of the obstruction, normally occurring from 5 to 10 seconds as well as 5 to 10 times during sleep. Once the individual becomes hypoxemic, he/she awakens and the airways become unblocked. The individual then falls asleep again and the event is repeated. The repetitive effort to maintain air passing through the airways causes a 30\% increase in volume and flaccidity of these structures. ${ }^{27}$

Snoring is defined as an inspiratory noise caused by friction of the soft tissues of the oropharynx due to partial obstruction of the upper airways. It is estimated that $35 \%$ of habitual snorers can develop obstructive sleep apnea-hypopnea syndrome (OSAHS). ${ }^{10}$ The main etiological factors of OSAHS are muscle hypotonicity (due to alcohol, drugs, muscle relaxants, sedentary lifestyle, ageing and mouth breathing), obesity (increase in adipose tissue in the upper torso and cervical region), increased volume of respiratory secretion, hypertension, hypertrophy of the tonsils and uvula, dorsal decubitus position during sleep, retrognathia and macroglossia. 7,9,10,11,27

OSAHS is considered a public health problem due to the related cardiovascular problems and the risk of work-related and traffic accidents stemming from daytime sleepiness and consequent mistakes when making decisions. OSAHS is also related to a poor quality of life, with the deterioration of neurocognitive aspects and subsequent negative repercussions on family/social relations and intellectual/ professional production. ${ }^{9}$

Depending on the severity of the condition, treatment can range from behavior modification to surgical procedures. ${ }^{7,23}$ Behavior modification includes sleep posture, weight loss, the suspension of alcohol and sedatives, and sleep hygiene. ${ }^{7,922}$ Patients who sleep in a dorsal decubitus position snore more loudly and experience a worsening in apnea events. This is due to the posterior movement of the dorsum of the tongue, soft palate and palatine uvula, thereby causing obstruction. It is therefore recommended that patients sleep in the lateral decubitus position..$^{9,16,22}$ Sleep hygiene consists of healthy attitudes and practices aimed at promoting continuous, efficient sleep, leading to a reduction in daytime sleepiness. Such practices include regular times for going to sleep and waking up, regular physical exercise (but not close to bedtime), light eating with a minimal interval of two hours prior to sleep, avoiding substances with caffeine and/or nicotine at least four hours prior to sleep, limiting the use of alcohol to the minimum and adapting the environment to favor restful sleep by avoiding incompatible activities, such as watching television, snacking and using the telephone. ${ }^{9,27}$

Intraoral mandibular advancement appliances to treat primary snoring problems and mild OSAHS are derived from functional orthopedic appliances, which are used in the treatment of retrognathia in patients in growth phase..$^{711,23,24,25}$ These appliances have been employed as a treatment alternative for patients with moderate to severe sleep apnea who are intolerant to the use of continuous positive airway pressure (CPAP). 1,2,7-13,21,23,24,25

This study focused in short-term efficacy and acceptance of a mandibular advancement splint (intraoral appliance) as an aid in the treatment of snoring and obstructive sleep apnea-hypopnea syndrome.

\section{METHODS}

The present study received approval from the Ethics Committee of the State University of Maringá (UEM/Brazil) and all subjects signed terms of informed consent agreeing to participate in the study. The sample was selected from 30 patients 
who sought treatment of snoring and sleep apnea between June 2006 and June 2007 at Dental Press Educational Center (Maringá/PR, Brazil). Seven were excluded due to excessive tooth loss leading to difficulty in adapting the splint, active periodontal disease, craniofacial disorders, upper airways obstruction or systemic disease. Three patients abandoned treatment one day after the installation of the appliance, reporting considerable discomfort. Thus, the sample consisted of 20 patients between 32 and 60 years of age (mean $=48$ years), 13 of whom were male $(65 \%)$ and 7 were female (35\%). Either the participants themselves or their spouses (which was more frequently the case) reported snoring or interrupted breathing during sleep.

All patients underwent polysomnography prior and 60 days after installation of the mandibular advancement splint (nighttime use). All exams were obtained from Neuromap 40i equipment (Neurotec, Itajubá-MG, Brazil) over an average of seven hours. Polysomnograms recorded AHI, snoring events, sleep efficiency, minimal oxygen saturation and heart arrhythmia.

Body mass index (BMI) was also recorded before and after polysomnograms.

The mandibular advancement splint used included an advancement tube-pin system (modified removable MPA, Coelho Filho, 1995). ${ }^{6,23}$ The tubepin connects the upper and lower plates to promote the forward movement of the mandible. Intermaxillary elastic bands (1/8-in) were placed on the hooks of the acrylic plates for better fixation of the mandible in a more forward position (Figs 1, 2 and 3).

The acrylic plates were limited to an average of $3 \mathrm{~mm}$ of functional free space to avoid neuromuscular discomfort. ${ }^{9,11}$ The appliances were constructed with the greatest possible mandibular advancement of each patient without discomfort.

The Wilcoxon test was used to compare pre and posttreatment findings, at 5\% significance level.

\section{RESULTS}

Table 1 shows comparison between AHI results at pre and post-advancement splint therapy exams. Table 2 demonstrates snoring recorded at pre and post-therapy evaluations. Table 3 presents BMI, minimum $\mathrm{O}_{2}$ saturation and sleep efficiency at the two experimental times. Table 4 shows arrhythmia records before and after splint therapy.

\section{DISCUSSION}

As reported in the literature, $5,8,12,13,17,18,19,21,25,26,28,29$ the mean apnea-hypopnea index (AHI) reduced significantly among the patients in the present study, that underwent intraoral splint therapy (mandibular advancement device). Mean AHI reduced from $20.89 \pm 17.9$ /hour to $4.43 \pm 3.09$ /hour.

Efficacy of mandibular advancement splint therapy has been related to AHI reduction. In mild to moderate OSAHS the treatment success using intraoral devices could range from 80 to $90 \%$. However, in severe cases this kind of therapy successfully treats 50 to $60 \%$, with partial efficacy. ${ }^{7}$ The present study corroborates those data. After treatment, 15 patients had no apnea or less than $5 /$ hour, four had mild apnea (5 to $15 /$ hour) and one had moderate apnea $(15>$ AHI < 30/ hour) ( $<<0.05)$. Among those patients who presented severe OSAHS in pretreatment phase $(n=5)$, two went to mild after treatment, one went to moderate, and two were considered successfully treated $(\mathrm{AHI}<5)$.

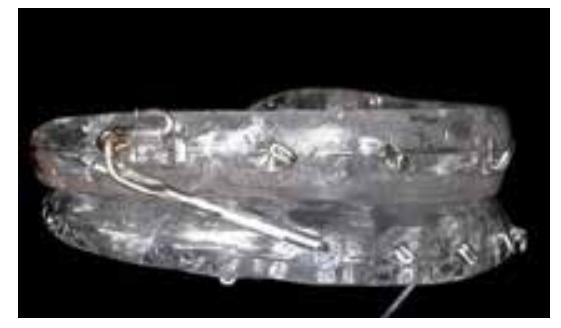

Figure 1 - Mandibular advancement splint used.

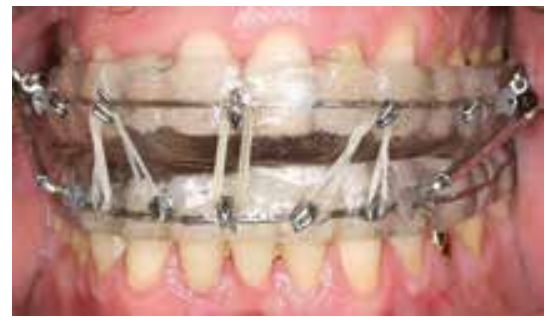

Figure 2 - Frontal intraoral view of mandibular advancement splint.

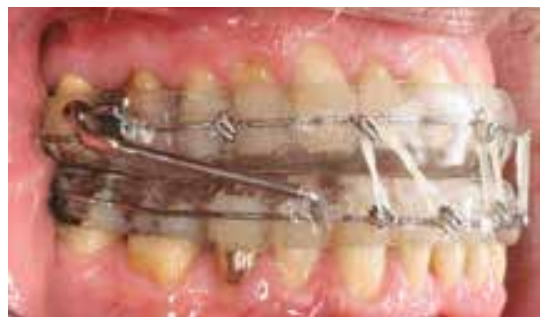

Figure 3 - Lateral intraoral view of mandibular advancement splint. 
Table 1 - Pretreatment and posttreatment mean apnea-hypopnea index (AHI), and level of severity distribution.

\begin{tabular}{cccc}
\hline AHI & pretreatment & posttreatment & significance \\
$\overline{\mathrm{X}} \pm \mathrm{SD}$ & $20.89 \pm 17.46$ & $4.43 \pm 3.09$ & * \\
Absent $(\mathrm{AHI}<5)(\mathrm{n})$ & 0 & 15 & $*$ \\
Mild $(5>\mathrm{AHI}<15)(\mathrm{n})$ & 9 & 4 & $*$ \\
Moderate $(15>\mathrm{AHI}<30)(\mathrm{n})$ & 6 & 1 & $*$ \\
Severe $(\mathrm{AHI}>30)(\mathrm{n})$ & 5 & 0 & $*$ \\
\hline$* p<0.05$. & & &
\end{tabular}

Table 2 - Pretreatment and posttreatment snoring severity.

\begin{tabular}{lccc}
\hline Snoring & pretreatment & posttreatment & significance \\
Absent $(n)$ & 0 & 6 & $*$ \\
\hline Mild $(n)$ & 4 & 13 & $*$ \\
Moderate $(n)$ & 9 & 1 & $*$ \\
Severe $(n)$ & 7 & 0 & $*$ \\
Total $(n)$ & 20 & 20 & \\
\hline
\end{tabular}

$\star p<0.05$

Table 3 - Mean and standard deviation of pretreatment and posttreatment $\mathrm{BMI}$, minimum $\mathrm{SO}_{2}$ and sleep efficiency.

\begin{tabular}{lccc}
\hline & pretreatment & posttreatment & \\
& $\overline{\mathrm{X}} \pm \mathrm{SD}$ & $\overline{\mathrm{X}} \pm \mathrm{SD}$ & $p$ \\
$\mathrm{BMI}$ & $27.07 \pm 4.49$ & $27.65 \pm 4.33$ & 0.109 (ns) \\
$\mathrm{SO}_{2}$ & $84.3 \pm 9.33$ & $92.75 \pm 2.4$ & 0.009 (ns) \\
\hline Sleep efficiency (\%) & $83.58 \pm 7.58$ & $88.13 \pm 4.45$ & $0.033^{*}$ \\
\hline
\end{tabular}

${ }^{*} p<0.05$.

Table 4 - Presence of pretreatment and posttreatment heart arrhythmia.

\begin{tabular}{lccc}
\hline Arrhythmia & pretreatment & posttreatment & significance \\
Yes $(n)$ & 3 & 0 & n.s. \\
No $(n)$ & 17 & 20 & n.s. \\
Total $(n)$ & 20 & 20 & \\
\hline
\end{tabular}

Among those patients who presented moderate OSAHS before treatment $(n=6)$, two presented mild and four presented AHI less than five after treatment. All patients presenting mild OSAHS before treatment $(n=9)$ were considered treated after the use of mandibular advancement splint.

In the present study the severity of the snoring reduced significantly, as documented by the polysomnograms, which revealed the absence of snoring in 6 patients (30\%), while 13 exhibited mild snoring (65\%) and only 1 patient exhibited moderate snoring $(5 \%)(p<0.05)$. Snoring could remain at some level although AHI reduces. ${ }^{7,13}$

Saturated $\mathrm{O}_{2}$ went from $84.3 \pm 9.33$ to $92.75 \pm 2.4$, however with no statistical significance $(\mathrm{p}>0.05)$. The quantitative sleep efficiency improved from $83.58 \pm 7.58$ to $88.03 \pm 4.45(p<0.05)$. There were no significant changes in BMI. Three patients exhibited pretreatment heart arrhythmia, whereas no patients exhibited heart arrhythmia during the post-treatment polysomnogram, although this data were not statistically significant. In general, those data confirm the benefits of related AHI reduction by using intraoral appliance.

It was reported that mandibular advancement appliance prevent the collapse of the upper airways during sleep by maintaining the mandible in a protrusive position, exerting extrusive forces and lingual movement on the upper anterior teeth, and mesial and vestibular movement on the lower anterior teeth, with significant long-term occlusal changes. ${ }^{14,15,20}$ It was also reported that the use of a mandibular advancement appliance alters the configuration of the upper airways, with a decrease in the length of the palate and an increase in the area of the pharynx, likely due to a loss of edema caused by snoring and repetitive apnea events. ${ }^{3,4}$ 
Although some dental alterations and other side effects may be undesirable in certain patients, the effective treatment of a life-threatening condition, such as OSAHS, is believed to supersede the maintenance of referential occlusion. Even in the presence of large dental movements, interruption of the treatment with an oral appliance should only occur when the patient accepts another treatment modality, such as continuous positive airway pressure equipment for the upper airways. ${ }^{7,8,14,15}$

Patients who require treatment for OSAHS are generally over 40 years of age, which is when periodontal disease begins to become aggravated. Thus, prospective studies involving a detailed periodontal evaluation are needed to determine a possible predicting factor of dental movement. ${ }^{14}$

As an oral appliance for the treatment of OSAHS is a life-long approach and the consequences of its use beyond six years are unknown, periodic clinical and radiographic exams are required to monitor the effects, which are at times beneficial and other times harmful, depending on facial pattern and pretreatment occlusion.

It is suggested that clinicians should be cautious in dental practice when treating patients with apnea using oral appliances if they have an ample anteroposterior airway and alteration in weight during treatment. ${ }^{17}$

Despite the positive results found in the present study, follow-up of these patients is necessary for determining long-term results regarding the snore and sleep apnea and side effects stemming from treatment.

\section{CONCLUSIONS}

Sleep quality improved in patients using mandibular advancement splint, but further studies evaluating longterm effects are needed. 


\section{REFERENCES}

1. Almeida FR, Bittencourt LR, de Almeida Cl, Tsuiki S, Lowe AA, Tufik S. Effects of mandibular posture on obstructive sleep apnea severity and the temporomandibular joint in patients fitted with an oral appliance. Sleep. 2002 Aug 1;25(5):507-13.

2. Almeida FR, Lowe AA, Tsuiki S, Otsuka R, Wong M, Fastlicht S, Ryan F. Long-term compliance and side effects of oral appliances used for the treatment of snoring and obstructive sleep apnea syndrome. J Clin Sleep Med. 2005 Apr 15:1(2):143-52

3. Almeida FR, Lowe AA, Sung JO, Tsuiki S, Otsuka R. Long-term sequellae of oral appliance therapy in obstructive sleep apnea patients: Part 1. Cephalometric analysis. Am J Orthod Dentofacial Orthop. 2006:129(2):195-204

4. Almeida FR, Lowe AA, Otsuka R, Fastlicht S, Farbood M, Tsuiki S. Long-term sequellae of oral appliance therapy in obstructive sleep apnea patients: Part 2. Am J Orthod Dentofacial Orthop. 2006:129(2):205-13.

5. Blanco J, Zamarrón C, Abeleira Pazos MT, Lamela C, Suarez Quintanilla D. Prospective evaluation of an oral appliance in the treatment of obstructive sleep apnea syndrome. Sleep Breath. 2005;9(1):20-5.

6. Coelho Filho CM. Mandibular protraction appliance for Class II treatment. J Clin Orthod. 1995:29(5):319-39.

7. Dal-Fabbro C, Chaves Jr CM, Tufik S. A Odontologia na Medicina do Sono 376p. Maringá: Dental Press Editora; 1 ed. 2010.

8. Gotsopoulos H, Kelly JJ, Cistulli PA. Oral appliance therapy reduces blood pressure in obstructive sleep apnea: randomized, controlled trial. Sleep. 2004;27(5):934-41.

9. Ito FA, Ito RT, Moraes MN, Sakima T, Bezerra MLS, Meirelles RC. Condutas terapêuticas para tratamento da Síndrome da Apnéia e Hipopnéia Obstrutiva do Sono (SAHOS) e da Síndrome da Resistência das Vias Aéreas Superiores (SRVAS) com enfoque no Aparelho Anti-Ronco. Rev Dental Press Ortod Ortop Facial. 2005:10(4):143-56.

10. Ito FA, Ito RT, Moraes MN, Sakima T, Bezerra MLS. Mecanismo de ação dinâmico do Aparelho Anti-Ronco (AAR): relato de um caso clínico. Rev Clín Ortod Dental Press. 2004;3(1):41-50

11. Ito RT, Moreira ACM, Bronzi ES, Yoshida AH, Ito FA, Yoshida N, et al. Aparelho Anti-Ronco: um enfoque multidisciplinar. Rev Dental Press Ortod Ortop Facial. 2000;5(2):48-53.

12. Lamont J. $\bigcirc$ efeito de tipos de splints para avanço mandibular sobre o Ronco e a Apnéia Obstrutiva do Sono. Rev Dental Press Ortod Ortop Facial. 1999;1(2):74-5

13. Lowe AA. Dental appliances for the treatment of snoring and obstructive sleep apnea. In: Kryger M, Roth T, Dement W. Principles and practice of sleep medicine. Philadelphia: W.B. Saunders; 2000. p. 929-39.

14. Marklund M, Franklin KA, Persson M. Orthodontic side-effects of mandibular advancement devices during treatment of snoring and sleep apnoea. Eur J Orthod. 2001 Apr:23(2):135-44.
15. Markland M. Predictors of long-term orthodontic side effects from mandibular advancement devices in patients with snoring and obstructive sleep apnea. Am J Orthod Dentofacial Orthop. 2006;129(2):214-21.

16. Orlando S. A parceria que promove um sono tranqüilo. Rev Bras Odontol. 2003:60(5):5-10.

17. Otsuka R, Almeida FR, Lowe AA, Ryan F. A comparison of responders and no responders to oral appliance therapy for the treatment of obstructive sleep apnea. Am J Orthod Dentofacial Orthop. 2006;129(2):222-9.

18. Otsuka R, Ribeiro de Almeida F, Lowe AA, Linden W, Ryan F. The effect of oral appliance therapy on blood pressure in patients with obstructive sleep apnea. Sleep Breath. 2006 Mar;10(1):29-36.

19. Otsuka R, Almeida FR, Lowe AA. The effects of oral appliance therapy on occlusal function in patients with obstructive sleep apnea: A short-term prospective study. Am J Orthod Dentofacial Orthop. 2007:131(2):176-83.

20. Pantin CC, Hillman DR, Tennant M. Dental side effects of an oral device to treat snoring and obstructive sleep apnea. Sleep. 1999;22(2):237-40.

21. Parker J. A prospective study evaluating the effectiveness of a mandibular repositioning appliance (PM Positioner) for the treatment of moderate obstructive sleep apnea. Sleep. 1999;22:230-1.

22. Paulin RF, Melo ACM, Ito RT, Sakima T, Reimão R. A apnéia obstrutiva do sono: considerações gerais e estratégias de tratamento. J Bras Ortodon Ortop Facial. 2001 dez.-2002 jan;6(36):488-92.

23. Ramos LVT, Furquim LZ. Aparelho para a apnéia obstrutiva do sono. Rev Clín Ortod Dental Press. 2004; 3(2):21-6.

24. Rider EA. Removable Herbst appliance for treatment of obstructive sleep apnea. J Clín Orthod. 1988;88(22):256-7.

25. Rose EC, Germann M, Sorichter S, Jonas IE. Case control study in the treatment of obstructive sleep - disordered breathing with a mandibular protrusive appliance. J Orofac Orthop. 2004:65(6):489-500.

26. Rose EC, Staats R, Virchow C Jr. Jonas IE. Occlusal and skeletal effects of an oral appliance in the treatment of obstructive sleep apnea. Chest 2002;122(3):871-7

27. Silveira M. A síndrome da apnéia obstrutiva do sono, o ronco e seu tratamento com o aparelho Apnout. J Bras Ortodon Ortop Facial. 2001;6(32):151-4.

28. Tan YK, L'Estrange PR, Luo YM, Smith C, Grant HR, Simonds AK, et al. Mandibular advancement splints and continuous positive airway pressure in patients with obstructive sleep apnea: a randomized cross-over trial. Eur J Orthod. 2002:24(3):239-49

29. Tsuiki S, Almeida FR, Lowe AA, Su J, Fleetham JA. The interaction between changes in upright mandibular position and supine airway size in patients with obstructive sleep apnea. Am J Orthod Dentofacial Orthop. 2005:128(4):504-12. 